\title{
Politics, Institutions, and Outcomes: Electricity Regulation in Argentina
} and Chile

William B. Heller and Mathew D. McCubbins*

Stanford University; University of California, San Diego

Risk, whether market or political, is an important dereminant of private investment decisions. One important risk, subject to control by the government, is the risk associated with the hold-up problem: governments can force urilitics to shoulder burdensone taxcs. to usc input factors ineffectively, or to charge unprofitable rates tor theit scrvice. To attract private investment governments nutust be able to make commitnctits to policies that are nonexpropriative (cither to contracts that guarantec very high rates of seturn or to favotable regulatory policies). These commitments. of course, must be credible.

Judgments about the credibility of commitments to regulatory poticies are based upon two political lactors: regulatory predictability and regime stability. Regulatory predictability implies that the tegulatory process, in which prices and levels of service are sit. is not athitraty. If the condition of regulatory predictabiliey holds, then invescors an forctist their returns over time and hence can calculate the value of their investment. If there is regine stabilicy. then there is minimal risk of wholcsile changes in the way the government regulates the industry-the most extreme type of change being the denial of property tights, or expropriation. We argue that there tharacteristics of the regulatory process are, in turn, important determinants of regulatory predictability: agenda control, reversionary regulatory policy, and veto gates. Morcover, regime stibility is also. in part, a function of these three characteristics. We examine our theory of political risk and regulatory commiument by comparing the cases of Argentine and Chilean electricity investment and regulation.

Keywords: Utility Regulation; Hold-Up Problem; Political Risk; Regulatory Commitment

${ }^{*}$ Corresponding author. 


\section{Introduction}

lisonomic development and long-term capital investment go hand in hand. Public utilitics, such as power and communications, ate particularly important in the relationship between development and investment: not only do utilities thenselves reeuire major capital inputs, but they are fundamental building blocks for coonomic development. Studying utiliries can therefore provide key insights into economic development.

Utilitics, as atractive and potent tools for redistribution, are particularly vuluncrable to political winds. Political interference in production and pricing of utility services tends to be inefficient, as economic criteria often are low on the list of considerations for political decisions.' Rolitically motivated redistributive efforts of en drive away sources of long-term capital investment and hence seriously impede economic development.

The tash of political exigency and ccomomic efficiency gives rise to a conundrum. On the onc hand, goveroments are central to utility development. Without them, vital investments might never be madc. On the other hand, government creates inefficiencies in two ways. First, they put up capital that the market might not otherwise provide. While this may hring about significant political returns for government, the market returns are often nil. Second and more importantly, they shield basic investment and pricing decisions from matket forces and open them up to political forces.

Risk, whether market or political, is an important determinant of private investment decisions. The greiter the risk, all else constant, the lower the level of private investment (World Bank 1995; Levy and Spiller 1996). (iovermments can, however, increase the level of private investment by reducing the political risks associated with capital-intensive industries. These political risis are well known and are referred to as the "hold up" probtem: governments can force utilities to shoulder burdensome taxes, to use input factors inelfectively, or to charge unprofitable rates for their service. Moreoves, due to the capital intensivity of urility production, exit is often diffcult, and thus governments can pursuc strategies that depreciate the asset value of the investment, essentially expropriating the capital through regulation (Williamson 1983).

While the hold up problem may deter investment, governments typically do not wisl to allow utilities to act as unrestrained monopolies. Thus, governments often seck to define a middle course. ${ }^{3}$ But, political whims are seemingly arbitrary and often seemingly capricious. To attract private investment in the first place, governments must be able to make commitments to policies that are nonexpropriative (either to contracts that guarantee very high rates of return or to favorable reguatory policies) on the one hand, and nonmonopolistic on the other. These comminuments, of course, must bo credible in the cyes of prospective investors (North and Weingast 1989, North 1990, Levy and Spiller 1996).

Judgments about the credibility of commitments to regulatory policies are based upon two political factors: regulatory predictability and regine stability. Regulatory predictability implies that the regulatory process, in which prices and levels of service are set, is not arbitrary. If the condition of regulatory predictability holds, then investors can forecast their returns over time and hence can calculate the value of their investment. If there is regime stability, then there is minimal risk of wholesale changes in the way the government regulates the industry-the most extreme type of change being the denial of property rights, or expropriation. ${ }^{4}$ If either of these two conditions are not met, then the apparent risk imposed by political circumstances is likely to lead investors to doubt the credibility of a regulatory commitment and thus will discourage private investment.

We will argue that three characteristics of the regulatory process are inportant determinants of regulatory predictability: assignment of agenda control over regulatory policy changes, the definition of the reversionary regulatory policy (i.e., the policy that obtains in the absence of policy change), and the number of veto gates (i.e., places in the process at which the holder of the gate can reject policy changes) in the regulatory process. First, if a veto player with a stake in the reversion has agenda control, then an investor can take comfort in the expectation of an ex ante veto. Second the more cxtremes the reversionary policy, all clse constant, the more likely is policy change; conversely, if the reversion constitutes some veto player's ideal policy, then policy change under normal circumstances is highly unlikely. With respect to the third characteristic, the more players there are who can veco proposed changes to existing policy, the more likely it is that the current policy will be stable. This observation hinges on an important premise: policy will change, under legal processes, only when there exists some altemative policy that all veto players prefer to the reversionaty policy. The likelihood of policy change, in turn, constitutes an important component of risk to investors, with more unstable policies posing the greatest risk, all clse constant.

Regime stability is an equally important determinant of political risk. Even when the regulatory process is stable and predictable, and returns to the industry ate sufficient for the predicted level of regulatory risk, the political risk involved with changes in government or changes in the goals of 
goverment may greatly increase the risk of any investment. The increase in rist ariscs because changes in government or changes in the goals of an existing government could generate unpredictable changes in the regulatory regime itself, luvestors must calculate the likelihood that a new government would change the sysem of regulation. Then, investors must consider the l'wel of authority that regulators in the new system might possess, as well as whecher regulators in the new system are likely to favor investors with karge sumk costs in capital investment.

We proced as follows. In the next section, we briefly review the relationship berween regulation and incentives for investment. In sections three and lour, we argue that incentives within the regulatory structure for private investment are not credible unless they are nested in a political context that makes them durable. Our argument hinges on the role of political institutions in protecting the status quo policy. In section five, we briefly consider the importance of regime stability for credible conmitment to regulatory ssructure. In section six, we then look at electricity regulation in its political and institutional context, in Argentina and Chile. While we find efficient and apparently similar regulatory frameworks in both countries, they came about through very different political circumstances and tegulatory mechanisms (for a detailed description of policies to promote competition in both countries, see Hogan 1996). Section seven concludes.

\section{Regulation and Investment}

The Capitat Asset Pricing Mexdel implies that investment will be determined, in part, by the risks associated with the investment. ${ }^{6}$ The higher the risk, the higher the expected return nust be to generate the same level of investment, all else constant. The Hip side is, if the rate of return is to be kepr below some extortionary maximum, then the risks must be reduced as wcll, all else constant.

Investors in public utilitics know there is a substantial amount of political risk associated with their investment. Political considerations may lead reguJators to "hold up" the utility by setting prices in the short run below the utility's long rus marginal cost (Williamson 1983). What makes this possible is the fact that two-thitrds of a utility's costs are, on average, capital costs, and thus setting prices too low in the short run will nor catse the utility to go bankrupt; however, this will eventually wipe out the utility's investment as its capital is depreciated. This will make the utility worthless.
In order to encourage investment, a governneot must be able to commit to a sufficiently high rate of return, or to liniting both regulatory uncertainty and regime risk. ${ }^{7}$ Either commitment, if eredible, allows investors to better predict the rate of return they expect from their investment. With respect to regulatory uncertainty and regine risk, such commitment is most credible if the gerernment is "constringed to obey a set of rules that do not permit leeway for violating commitments" (North and Weingast 1989, 804; sec also, Willamson 1985, 48-49; Milgrom, North, and Weingast 1990; Root 1994: Levy and Spiller 1996). The greater the uncertainty, all else constant, the less long-term capital investment will accruc.

Levy and Spiller $(1994,207)$ point out that executive and legislative discretion is often inversely correlated with credibility. ${ }^{8}$ For Levy and Spiller, a strong and independent judiciary can constrain both of these branches of government. If independent justices are willing to decide against the govcrnment, then the courts can brake government action. In essence, courts that can and will check actions taken by other branches of governmenti.e., cours that have a veto on policy-can enhance the credibility of government commitmenr to "regulatory governance."

It is often the case, however, that courts are not independent of the executive and the legislature; within certain political systens, it is impossible to create independent courts. The issue, we think, is not really the courts per se, but rather how easy it is to change regulatory structures and procedure. In order to understand investment and regulatory decisions, cherefore, it is necessaty to examine regulatory structures on the one hand, and the possibility that the regulatory structures will themselves be overturned or ignored, on the orher.

\section{Institutional Determinants Of Regulatory Predictability: Veto Gates, Reversionary Policy, And Agenda Control}

A necessary condition for policy change is that policy makers prefer some policy other than the status quo. There are a number of reasons why changing policies might become attractive. A new government might come to power, reflecting new (or hitherto ignored) demands and priorities; better information might become available to policy makers (via generational replacement or new advisory teams, for examplc) that supports more efficient alternative policies; policy makets might want to adjust policy in response to extragovernmental pressures, as from interest groups or rival political par- 
tics: or technology may develop so as to render old tegulatory structures irrelevant or cven harmful. Each of these possibilities carries the danger that policy change will reduce the return to investors with sutk costs in the affected industries.

Commitment to regulations and, hence, reduction of political risk, reguires a commitment to a particular tegulatory structure and procedure so that it is difficult for the government to change regulations even if policy mutcome's are distastefil to it. Specifically, there are three features of the proass that investors can consider in order to predict the consequences of their actions and thus to make reasoned investments.

lïrst. investors can identify who holds veto power over policy change. In the Unitcd States, for example, utilities hold an ex ante veto in that they contrel the proposal power to change lates. Public utilities commissions can veto proposed changes. If any veto player has a stake in current policy, then the status guo will endure, thereby protecting the expected return on investments. This assumes that the reversionary outcome-the result of failing w) propose or to enact new policy-is the status quo. The teversionary outcome is, thercfore, a second key variable that potential investors must consider. In the United Statcs, for example, the reversionary outcome is the existing rate structure and service schedule. Finally, an investor would be wise to consider the agenda setters, who dictate whether and what proposed changes will be considered. In Chile, for example, it is the regulatory agency that proposes changes to the existing policy. We will discuss the dynamics of ach of these elements of the policy-making process in turn.

$A$ common approach to institutitg a commitment is to increase the numher of veto players with atuthority to block policy changes. A political process that increases the number of veto players, while making no other changes, will be nore biased toward maintaining reversionaty policy." Hence. government commitment to stable policy or process is easier in presitiential, bicameral-legislative (where the chambers have equal powers), and federal constitutional systems, as well as multiparty systems where no single party controls a majority of legislative seats, for in each case we see a mulciplicity of veto players.

The reversionary outcome is the outcome to which policy reverts if no ncw proposal is passed. Often, the reversionary outcome is the status quo; but, this need not be the case, as illustrated by policies that are subject to sunset provisions. Under such policics, the reversionary outcome is not the status quo, but tather the cventual cessation of existing policy. Federal spending in the U.S. for the Department of Education, for example, reverts to $\$ 0$ in the abscnce of new appropriations for it in the annual budget. With regard to regulatory policy, a reversionary outcome could include a sunset provision that calls for deregulation via termination of the relcvant regulatory agency.

The combination of agenda control, veto powes, and reversionary outcome affects the stability of regulatory policy. Thus, the level of private investment in urilities is, at least partially, a function of these three institutional features.

\section{Modeling Policy Making}

To evaluate how the reversionary outcome determines the equilibrium policy. it is useful to employ a simple spatial analogy. Herc, we adopt the method used by Hotelling (1929), as we assume that players have ideal points along a unidimensional policy space. From models like these, we can easily derive equilibria for various agenda structures where the agenda structure captures the key clements of the regulatory process. Prospective investors can use the implications of these spatial models to evaluate how well their investment will be protected.

First, let us consider a simple agenda structure where agenda control is granted to the regulator and the utility does not have a veto over changes from the reversion, $Q$. Under this scenario (and making the usual spatialmodeling assumptions about preferences, ${ }^{10}$ most importantly that players have single-peaked preferences), the regulator would pick its ideal point, $R$, as shown in Figure $1(\mathrm{a})$. In this figure, the utility with ideal point $I$ prefers the regulator's proposed policy change to the reversion (for $|I-R|<|I-Q|)$. The result of this process need not profit the utility, however, as can be seen in the situation depicted in Figure 1(b). In this case, the utility is left worse-off by the regulator's proposal (because $|\mathrm{I}-\mathrm{Q}|<|\mathrm{I}-\mathrm{R}|$ ).

Next, consider a slight variation of this agenda, where the utility is granted a veto over changes to the reversion policy. Under this regulatory process, the utility has a much better chance to protect its interests. For example, reconsider Figurc 1(b), where $y$ is a point such that I no longer prefers to retain $Q$ (but I prefers $Q$ to $y+\epsilon$ ). Given these preferences and an agenda that allows the utility to veto policy change, the regulator would offer the utility a proposal at $y$. The regulator selects $y$ becutse it is its best strategy in anticipation of the utility's veto power. If the regulator were to select a point to the right of $y$ (such as $y+\epsilon$ ), then the utility would no longer be indifferent but would instead prefer the reversionary outcome $Q$ to the proposed change. " This would make the regulator worse off, as it would get $Q$ instead of $y$, which it prefers. Thus, by changing the regulatory 
(a)

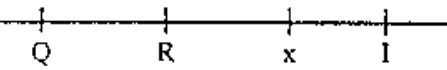

(b)

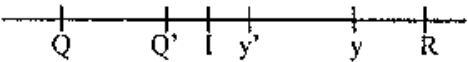

(c)

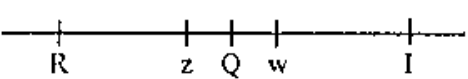

IIC:CiRf: I A Sparial Alodel of Agenda Power and Reversionary Policy.

process, in granting the utility a veto, policy moves from $\mathrm{R}$ to $\mathrm{y}$ and the utility is made better off.

ln Figure $1(c)$, the reversion point lies between the utility and the regulator. 'Thus, there is no proposal that makes both the regulator and the utility better off than the reversion. Let $\mathrm{z}$ be the point $\mathrm{Q}-\epsilon$. So, for cxample, if the regulator proposes $z$, then the utility will veto the proposal because $|I-Q|<|I-z|$. Let $w$ be the point at $Q+\epsilon$. Although the utility would approve $w$, the regulator would not propose it under this agenda structure because it would be worse off than it is at the reversion $(|\mathrm{Q}-\mathrm{R}|$ $<|w-R|)$. Thus, the equilibrium outcome for Figure $1(\mathrm{c})$, given the simple agenda structure here, is the reversion.

When rhe utility has veto authority, it prefers the outcones in Figure $\mathrm{l}(\mathrm{l})$ and Figure 1(c), because they ate closer to its ideal point, I. Also, in the case of Figurc $1(\mathrm{~b})$, as the reversion approaches $\mathrm{I}$, moving from $\mathrm{Q}$ to $\mathrm{Q}^{\prime}$, for cxample, the equilibrium outcome moves closer to $I$ as well (from $y$ to $y^{\prime}$ in the figure), thereby increasing the utility's ability to infiuence the outcolve.

Finally, consider the agenda structure where the utility initiates changes to the regulatory policy, and the regulator has a veto. In this case, given the sconario of Figure $1(a)$, the utility's best strategy is to select $x$, where $x$ is a point such that $R$ no longer prefers $Q$. The utility selects $x$ for the same reasons that the regulator, under paraliel conditions, selccts y in Figure 1(b). The cquilibrium outcome in Figure 1(a), when the utility is the agenda serter and the regulator has a veto, is $\mathrm{x}$. The rcason why $\mathrm{x}$ is the equilibriun outcome is because the regulator prefers $x$ to $Q$ (for $|R-x|<|R-Q|$ ) and will therefore accept the utility's proposed change, $x$. In Figure 1(b), the same agenda structure leads to an equilibrium outcome at I. ${ }^{13}$ The equilib- rium outcome is I because the utility would propose its ideal point, which the regulator prefers to $Q$ (because $|R-l|<|R-Q|$ ). The new policy, I, makes both players better off.

The notion of vetoing a policy proposal implies that there is some other policy-the reversionary policy-that is preferted. The reversionary policy can limit the number of feasible choices, as when it divides veto players or when it is itself the most preferred policy of at last onc veto player. When it is relatively more extreme, by contrast-that is, as it becomes more likely that all veto players (and, of course, whoever has proposal power) will agree on some alternative to it-the reversion becomes less important to policy outcomes. The more extreme the reversion, therefore, the less restricted is the range of alternatives that can be produced by the regulatory process.

In order to anilyze regulatory policy, we must look not only at regulatory incentives but also at the authority and preferences of regulators, the ease of changing regulatory processes, and reversionary policy. Further, especially in light of the past experience of many low- and middle-income countries, we should consider what happens when kcy players are denicd a veto. Formal vetoes mean little when they ate unbalanced-controlicd by one or more players with identical preferences. Where veto gates are few or unbalanced and exclude important actors such as the military, we must consider also the specter and consequences of dissatisfaction, not only with regulatory outcomes and process, but also with the entire political structure.

\section{The Determinants Of Regime Stability}

The determinants of regime stability are unity of purpose and separation of powers (Cox and McCubbins 1996). If there is a unity of purpose among policy makers with respect to regulatory policy, such that the sources of disagreement among competing factions do not include the structure of regulatory decision making, then the process by which regulatory decisions are made will be stable. Such unity of purpose among policy makers could arise if division would allow those who could copple the government to come to power, or if there is a unity of purpose among those to whom the government is accountable. As long as this unity of purpose holds, we expect that the regulatory process will be stable.

Suppose, however, that policy makers are divided on the issue of regulatory structure such that each of the competing factions prefers an alternative to the status qun yet there is disagreement over which of the alternatives should be chosen. In other words, unity of purpose no longer exists. Then, 
for the existing regulatory structure to be stable, the competing factions must be able to chack aich other's proposed changes. That is, a system of separation of powers must exist, in a divided society, so that competing lictions hold a veto over proposed changes in the existing regulatory institations (Cox and Mckelvey 1984; Tsebelis 1993). Otherwise, chaos is a likely result. Under separation of powers, the deck is stacked in favor of preserving the status quo which allows for regulatory stability.

\section{Utility Regulation In Argentina And Chile}

In the next two sections, we turn our attention to the specifics of agenda antrol, vero authority, and political risk and regime stability in Argentina and Chile. These two countries, with their similar political systems but different regulatery rules and outcomes, present a stark contrast. ${ }^{\text {1' }}$ One of the licy regulatory differences hetween the two countries is where agenda power lies: in Chile, the regulators mostly control the agenda; in Argentina, by contrast, the regulators' agenda power is quite limited. Argentine regulators may exercise agenda power only at speciffed intervals and, in fact, they share agenda at hority with producers, distributors, and even users. ENRE, the national dectricity regulatory body in Argentina, can propose new policies unilaterally, for example, only when issuing or renewing licenses. It must respond, however, to proposals for change (e.g., to alter price-setting formulas or tariff structures) cmanating fron consumers as well as generators and distributors. While the government's (specifically, the Secretaria de linergás) 20 percent-shate in CAMMESA (Compaña Adninistradora del Mercado Mayorista lícécrico Sociedad Anónima-the corporation that administers the wholesale electricity market) gives it special veto powers over decistons taken by CAMMESA's board, it has no more authority to make proposals in that arca than the generators, transmission companies, and distributors witl whom it shares ownership.

This difference in the regulator's' agenda power can be a subtle bur inportant factor in investor calculations of expected returns. To anticipate the discussion below, in Chile, policical tisk is minimal. The Constitution makes it very difficult for politicians who want to change the regulatory regime to succed and, moreover, the general success of liberalizing policies means that those who watt to roll them back are in a decided minority. The regulatory regime itself is quite formal (i.e., specific about what can be changed, how much, and under what circumstances), so that while regulacors hive a great deal of atthority to propose policy change, they are very limited in the proposals that they can make. Under these conditions, investors have little to fear from rogue regulators and so should be untroubled by the CNE's agenda authority.

In Argentina, political risk has decreased, but it is still not clear whether the present favorable investment climatc is well-entrenched or merely dependent on the whims of President Ménem and his cconomic team (hence the international as well as domestic concern over Ménem's sacking of Economy Minister Cavallo). Under these circumstances, investors have held on to substantial agenda control, which can serve as added protection against the policy whims of elected officials.

\subsection{Electricity Regulation and Regulatory Outcomes in Argentina}

We now curn to an cxamination of politics and electricity regulation in Argentina and Chile. In this section we examine the privatization and concomitant regulation of Argentine electricity. To this end, we first sketch the extent to which the electricity sector is privatized. We next look at ratesctting rules and processes. The structure of rate setting defines veto gates, reversionary outcomes, and agenda control in utility regulation. We then situate these rules within the larger political context of electoral, legislative, and constiturional processes. By identifying who can propose and who can veto policy change, as well as reversionary policy, we can formulate and cest hypotheses against available data on tates and rate structures.

\subsubsection{Prinatization and regulatory prolistability}

Privatization and hence regulation of electric utilities in Argentina is a new phenomenon. ${ }^{15}$ The current system, designed for private cnterprisc, is unique in that it divorces utility earnings from their capital-investment costs. Of further interest, while provisions for rate of return on capital have been abandoned, the regulatory scheme essentially provides for rate of return on variable costs such as labor, administration and organization, fuel, and so forth.

The government and the workers of SEGBA (Servicios Eléctricos del Gran Buenos Aires) reached an agreement on selling SEGBA (with some shares going to workers) in September 1989 (González Fraga 1991, 95). By 1994, the government had sold majority stakes to three distribution firms, serving a total of $3,954,333$ customers; six transmission companies, accounting for a total of 14,97 I kilometers of lines; and 21 generating plants, ranging in capacity from 47 to 1400 megawatts, for a total capacity of 
10,203 megawats. 'The government held 39 percent of shares for itself, distributed 10 percent to workers, and sold the rest on the stock market. " It sold berween 51 and 60 percent of generating plant shares on the stock matket. kecping between 30 and 47 percent for itself and distributing the balance to workers in the iffected plants (ENRE 1994a, 20 and 25, Table I1). Purchasers involved in the original silte jucluded Chileun companies as well as companics from France and Spain (Hannon 1993. 96; Rausch 1993. 185). P'rivatization of so many state holdings in just two years suggests that investors find the Argentine regulatory formula attractive.

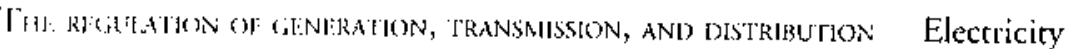
generation, transmission, and distribution are regulated tunder law 24065 and decree 1398/92. As in most countries, there are different regulatory procedures for each of these three aspects of electricity provision.

Elcctricity generation is essentially unregulated, with no need for (prospec(ive) gencrators to obtain permission prior to building or adding to generaring facilities. When it comes to selling clectricity, generatots operate in two markes: In one, they can contract to sell their output among themselves and directly to distributors and large consumers, at any price that both parties can agree to (law 24065 , Art. 5). ${ }^{17}$ In the second, they supply energy at che "spot" price" on the basis of the marginal cost of meeting immediate demand (FNRE 1994a, 39-40). ${ }^{19}$ Generators "also are remuncrated for ileir available capacity," throtigh a fixed, per-megawatt sum that is added into the spot price (ENRE 1994a, 40).

Electricity transmission and distribution are classified as public services. Transmission companies may not buy and sell electricity. Like distributors, lhey are considered natural geographical monopolies and are obliged to supply access to transmission lines as long as they have capacity to spare, for which they charge a fixed transport fee (sce note 22). Distribution companies (but not transmission companies) can buy their energy either directly from a generator for a contracted price, or they can buy electricity in the "producers" marke" 20 at a three-month "stabilized" spot price intended to approximate what would prevail in a frec market (ENRE 1994a, 46). ${ }^{21}$

The national electricity regulating body (Ente Nacional Regulador de la Lectricidad, or ENRE) regulates transmission and distribution companies and, for the most part, both are covered by the same rcgulatory provisions. ${ }^{22}$ The transmission and distribution companies control the agenda, insofir as they can propose changes to rates, but they also must obtain permits from ENRE in order to build, operate, or extend their facilities (law 24065, Art. 11). The process through which such permits are granted is replete with public hearings and public notice and comment (much like that provided for in the US Administrative Procedure Act; sec law 24065 , Caps. 8 and 9; sec also Resolución ENRE No. 39/94). T'hey must also obtain ENRE approval for mergers, buyouts, or service curbacks; such approval, like approval of operating licenses, requires a well-defined process of public notice, hearing, and comment. The teversionary policy when ENRE rejects a request is the status quo policy (i.e., ENRE holds an ex ante veto over regulatory change); should ENRE fail to act, neither rejecting nor accepting a request, then policy reverts to the utility's proposal.

PRICNG LXDER THE NEW REGIME While the wholesale electricity market is largely unregulated, with prices subject basically to the pressures of supply and demand, the retivil market is not. Distributors operate regional monopolies under five-year licenses from ENRE and, therefore, do not face markct competition. The licenses stipulate a tariff structure, which then serves as the basis for all price adjustments.

The reversionary pricing policy, then, is the initial tariffs agreed to at the beginning of the licensing period, adjusted according to a number of critcria set forth in the electricity law. As circumstances and technologies are not constant, distributors may request adjustments to the initial structure, thereby controlling the agenda over price changes. Such requests must be approved by ENRE, which holds veto authority over them. Rate-change requests are subject to challenge on several fronts (law 24065, Art. 45; Resolución ENRE No. 39/94); ENRE may call hearings on rate adjustments, for example, if it believes that a company's rates are "unjust, unreasonable, unjustifiably discriminatory, or preferential" (Law 24065, Art. 48; and see Resolucion ENIRI: No. 39/94). Th the event of ENRE inaction (i.c., no ruling within 120 days), the licensee may institute its requested changes as if they had been approved. ${ }^{23}$ Thus, the distribution companies control, to some extent, the reversionary policy. Together with their control over the agenda, the regulatory process should seem quitc attractive to investors, as it is predictable and controllable. If the initial tiriffs in the contract are favotable, then investors should be quite happy to commit their resources.

In many countries, including such disparate cases as Japan, the United States, and Mexico, utility prices are regulated so that residential users are charged a lower rate than other types of users. Prices fit this description in Argentina when its electric utilities were statc-owned enterprises. Moreover, prior to privatization, prices were often unpredictable (Covarrubios and Maia 1994a), particularly for commercial users, and the tariff structure favored residential consumers. As a general rule, industry tends to pay less for electricity than other consumers, due both to its relatively elastic demand for energy (Kahn and Gilbert 1994, 13) and to the fact that energy 
for indistry tends to be cheaper to deliver because it comes in larger quanrities and at higher tension. If prices reflect cost of delivery, then the ratio of residential to industry prices, at any time, should be greater than 1 . As can be secn in Table l, before privatization in 1989-90, the ratio of residential to industrial prices was in fact above unity. Table I also shows that, prior to privatization, low-demand residential users were charged far less than high semand residents, commercial users and small industry.

In the leadup to privatization, however, prices were adjusted. While commeccial uscrs were still charged more than any other class of consumets, by 1991, low and high demand residential users were facing roughly equal prices and small and large industry both saw significane price drops. These changes more than doubled SEGBA's total average tariff from spring 1990 to spring 1992 (Covarrubios and Maia 1994b, A-40, Table II). This dour bling in the total avernge tariff, given the increase in electricity consumption overalt (sce Table II), implies that the utility's revenues increased greatly and that utilities werc increasing capacity to fulfill previously unmet demand. ${ }^{21}$ The increase in prices for residential consumers is a non-trivial change wich respect to revenue for the utilities, since residential consumption is both inclastic and accounts for nearly $50 \%$ of overall electricity sales (see Table III). We also see evidence of increasing profitability for Argentine electric utilities. For example, consider EDENOR, the electricity distribution company for the northern region of Argentina. EDENOR's balance sheet reported net losses in 1992 and 1993 but they have begun to turn it around with net gains in both 1994 and 1995 (see Table IV). ${ }^{25}$ This increase in profitability is attractive to investors, particularly if they are convinced that the existing regulatory structure is sustainable. In fact, the utility's agendit setting role with respect to policy change offers the investor confidence in regulatory sustainability, and thus gives rise to regulatory predictability.

The regulatory regime that was created for privatized electric utilities privileges status-quo tariffs. Privitte utilities, under this new structure, retain monopoly proposal power for changes in regulatory policy. Rationa! utili-

17abil: I l'te-l'rivatization Rate Ratios by Consumption Catcgory (SEGBA)

\begin{tabular}{|c|c|c|c|}
\hline Rerion of Prices Betuects & 1987 & 1988 & 1991 \\
\hline Residential Low/Large Industry & 1.48 & 2.47 & 2.10 \\
\hline Silliah Irrlustry/Large Industry & 2.45 & 2.98 & 1.58 \\
\hline Residential Higl/Large Industey & 2.38 & 2.41 & 2.07 \\
\hline 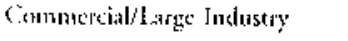 & 2.38 & 2.93 & 2.63 \\
\hline
\end{tabular}

Shurse: Heiditrian and Wu 19\%4. 20

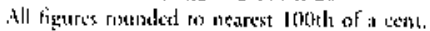

TABb1, II Thal Llecoric Fincrg! Consumprion in Argentinu

\begin{tabular}{|c|c|}
\hline $\operatorname{rin}$ & 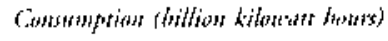 \\
\hline 1990 & 46 \\
\hline 1991 & 49 \\
\hline 1992 & 5.3 \\
\hline 199.3 & 58 \\
\hline$\{104 d$ & 61 \\
\hline
\end{tabular}

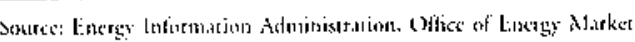

ties, therefore, will only make proposals for policy change when it will guarantee higher rates of return than the status quo. The regulatory process, replete with heatings and open chaltenges, essentially gives companies a veto over new policy and thus makes regulatory policy predictable. Hence, by adjusting prices before privatization in order to make SEGBA profitable and by credibly commitring to a regulatory structure that stacks the deck in favor of the status quo, the government guaranteed the preservation of tarifls that were favorable to investment. The new pricing structure was credible as long as the regulations underpinning it were seen as stable. This is the sopic to which we next turn.

\subsubsection{Regint stability}

The new regime in Argentina is attractive to investors because utilities control the agenda over proposed tariff changes and because the reversionary price structure was set up to be profitable. But why would investors believe that the regulatory regime is credible? After all, Argentine politics in the twentieth century have been typified by intense, often violent, class and urban-rural conflict. The provinces' strong voice in politics magnified this conflict. Further, political leaders usually have faced both an interventionist military and an opposition that sought radical economic redistribution.

Political control was particularly desirable because the state owned key sectors of the Argentine economy. State ownership of public utilities was one of the few things that Radical party politicians and Peronists agreed on.

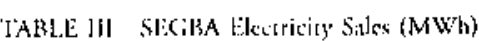

\begin{tabular}{lccc}
\hline Fitr & Residentint & Commerial & Indistriat \\
\hline 1990 & 5187890 & 1425959 & 4226193 \\
1991 & 5554000 & 2134881 & 4074052 \\
\hline
\end{tabular}

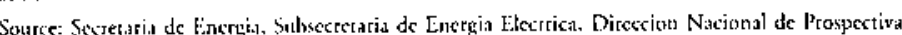




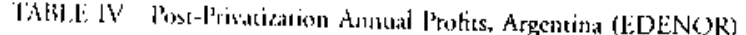

\begin{tabular}{|c|c|}
\hline biter & Net hrowe (thoustandes of pesias) \\
\hline $89 \%$ & -52.304 \\
\hline $\mid \omega 9,3$ & $-65,814$ \\
\hline $10 \%$ & 1.386 \\
\hline lams & 46,530 \\
\hline
\end{tabular}

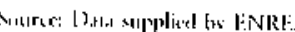

Whatever the basis for this agreement-cconomic philosophy, nationalism, political experience, ideology-it effectively opened the coffers of stateowned enterprises to the party in power. As a result, politicians in power have sought two things above all else: to eliminate the opposition and to extract is much as they could from the economy before they themselves were removed from office.

For most of the 20th centuty, Argentina's governments have been unified, either under Peronist, Radical/Conservative, or military control. During their tenure in office, each had opportunities to unilaterally impose its own policies. But, the separation of powers system in Argentina allows for the division of purpose within the society to yield divided government. Indeed, in the 1980s, President Alfonsin faced a divided legislature. Divided govcrmment, in this instance, scemed destined to follow the same pattern of policy stalcmate and political upheaval as in the past, but it did not. The violence of the past caused the parties to compromise in this case: Alfonsin structured a compromise between the moderate factions within both his own Pcronist Party and the Radicals who held the legislature. It was under these conditions that privatization was possible (Hill and Abdala 1996).

The 1988 elcctions brought unified government back in under the Peronist Partido Justicialista (P]) (Jones forthcoming), but the newly elected l'cronist president, Ménem, and other moderate Peronists proved willing to work with moderates in the Radical/Conservative party even against the wishes of their nore extreme copartisans. With the military on the sidclines and the public sector in shambles, control of government was both less tcruous and less profitable than in the past. Thus, while there are still some risks of investing in Argentiua relative to investments in other developing countries, the new political cnvironment and new regulatory tegime reduced the risks in the near tcrm, making investment more attractive and privatization feasible.

Indecd, the new political climate is reflected in the setting of electricity rarifts. Table $V$ provides a representative glance at electricity rates for differcnt user categories from the moment of privarization to April $1994 .{ }^{26}$ This

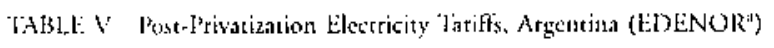

\begin{tabular}{|c|c|c|c|c|}
\hline Usrrs & $C C_{s s} j^{\prime}$ & Inithat Thofl & $A p-93$ & Nor $9 \mathrm{~s} / \mathrm{s}$ pr st \\
\hline \multirow[t]{5}{*}{ Sm, } & 'II-RI & 0.061 & 0.061 & 0.066 \\
\hline & $\mathrm{T} 1 \mathrm{~K} 2$ & 0.056 & 0.055 & 0.051 \\
\hline & $11-(i)$ & 0.108 & 0.108 & 0.104 \\
\hline & $\Gamma 1-\mathrm{GI}$ & 0.083 & 0.083 & 0.078 \\
\hline & $\mathrm{I} \mid-(3,3)$ & 0.06 .3 & 0.062 & 0.057 \\
\hline Micdienton & $\mathrm{T}_{2}$ & 0.067 & 0.067 & 0.062 \\
\hline \multirow[t]{3}{*}{ L.arge" } & $T 3-B \Gamma$ & 0.048 & 0.047 & 0.042 \\
\hline & $\mathrm{T} 3-\mathrm{M} / \mathrm{T}$ & 0.046 & 0.045 & 0.040 \\
\hline & $\mathrm{T} 3+\mathrm{AT}$ & 0.043 & 0.043 & 0.038 \\
\hline
\end{tabular}

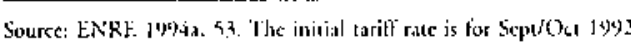

Exkluding thatges for public lighring, cic.

"User aldasses are defined as follows:

Loit' demand:

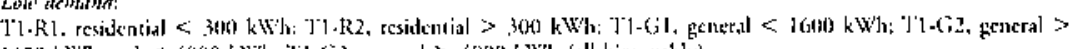

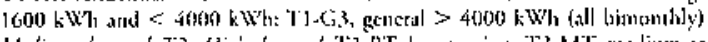

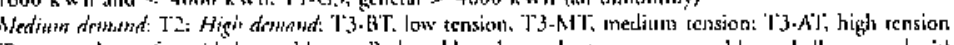

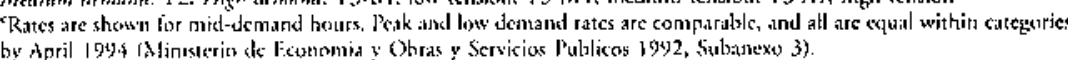

table shows that the price adjustments made before privatization appear to have continued after privatization: industry's electricity prices have dropped while residential prices have remained faitly steady, if not increased. By and large, however, prices have been fairly stable, far more stable than in previous years.

The compronise policies of the early 1990 s wete followed by some important political reforms. Prior to 1994 , senators were elected from twomember districts by plurality rule in provincial legislatures. It was thus unlikely for a province to have split party representation in the Senite. The rules governing senatorial elections were anended in 1994, and senators now are directly elected in three-member districts under a rule that gives two seats to the party winning fle most votes, with the second-place party taking the third seat. Thus, where the old electoral rules reinforced the "winner-take-all" pathology attributed to presidential systems (Linz 1990), the 1994 constitutional amendments undercut this tendency. Furrlaer, the amended Constitution not only reduces provincial governments' power, but also the stakes of interprovincial conflict, by prohibiting unfunded mandates and stipulating revenue sharing among provinces (Art. 75.2). By institutionalizing compromise (cf. Lijphart 1984) and ensuring that the mafority cannot deny vital resources to the minority, these reforms made reversionary policy a more acceptable alternative and hence increase the importance of each branch of government's veto authotity. In Madisonian terms, the teforms made it feasible for ambition to counter ambition and, 
thus, give life to constitutional checks. This makes all policy change, and particularly change that runs roughshod over all opposition, much more difficult.

What do these recent changes mean in ternss of invesement and prices? We :rigue that willingness to invest is a function of reversionary policy plus the interaction of regulations, regulatory processes, and political stability. In Argentinat, there are three distinct periods of interess with respect to investment and regulatory prices-pre-1992, 1992-1994, and post-1994-corresponding to houts of privatization and of constitutional revision. With respect to pricing, we should observe that utility pricing prior to 1992 should follow a political logic, not an economic one. While we do not precend to analyze policy makers' incentives we do expect prices to be erratic during chis period, with unpredictable changes as political circumstances change, and for the tariff structure to favor the constituents to whom the politicians are electorally accountable. Table VI presents average tariff levels for residential, commercial and industrial users of electricity for April and October, 1988-1991. These data slow considerable price instability. The data presented in Table I also support the latter contention, showing that the ratio of prices favored certain usser groups over others.

We would also have expected prices to then stabilize in 1992 for two reasons. First, the government sought to create an initial tariff to encourage investment upon the initiation of privatization. Second, the utilities under the new regulatory structure retained monopoly proposal power for changes

TAI3E[E V'] Argentilik Tirite Structure: 1988-1992 (US\$ $/ \mathrm{kWh}$ )

\begin{tabular}{|c|c|c|c|c|}
\hline & & Residemid Thiff & Commeriat Tariff & Indsutvint Theriff \\
\hline \multicolumn{5}{|c|}{$\operatorname{Pre} \cdot \mid y)_{2}$} \\
\hline & $A_{p} r-8 s$ & 6.28 & 8.05 & 3.00 \\
\hline & Oa- $8 \mathrm{~s}$ & 8.9 .3 & 14.12 & 5.68 \\
\hline & Apr-84 & 2.30 & 3.70 & 1.43 \\
\hline & Ot+ 89 & 3.83 & 10.17 & 5.58 \\
\hline & Aptr-90 & 1.9.3 & 14.02 & 7.14 \\
\hline & $(x a-5)$ & 11.16 & 17.88 & 8.70 \\
\hline & $\left.\langle y|-{ }^{-1}\right\}$ & 9.59 & 10.80 & 6.42 \\
\hline & $\left.O()_{0}\right) 1$ & 9.49 & 10.68 & 6.35 \\
\hline \multicolumn{5}{|l|}{1092} \\
\hline & Jun-Fas 92 & 8.52 & 15.32 & 9.04 \\
\hline & Nat-Dece? & 0.71 & 16.94 & 9.94 \\
\hline
\end{tabular}

Sem:ex: (1) 11$)$ : from the inicial tariff. Indecd, as Table VI indicates, prices stabilize in 1992 for all three user categories. Table $V$ offers evidence that tariffs were stable between 1993 and 1994.

Investment should be lower where price risk and political uneertainty are high (i.e., an adequate teturn is unccrtain), all else constant. Thus, we should observe that private investment should have increased from 1992 to the present. Figure 2 shows that installed capacity has increased for at least the years in which we have data (installed capacity is a reasonable proxy for investment in generating equipment). Furthermore, utilities will shy away from major investments if they fear that they won't be allowed to recoup their costs, much less earn a profit. This implies, for example, that in a situation of political uncertainty, distributors will invest relatively more heavily in variable inputs for maintaining the existing grid instead of investing capital to upgrade or extend it. This is a testable proposition, although we do not have the data to check it. If we did, we would expect to observe a clear increase in capital investment by distribution companies in the wake of the 1994 constitutional revisions and their confirmation by the public with the peaceful reelection of President Méncm. Generators, as we have shown in Figure 2, also increased their investments as their future became more secure.

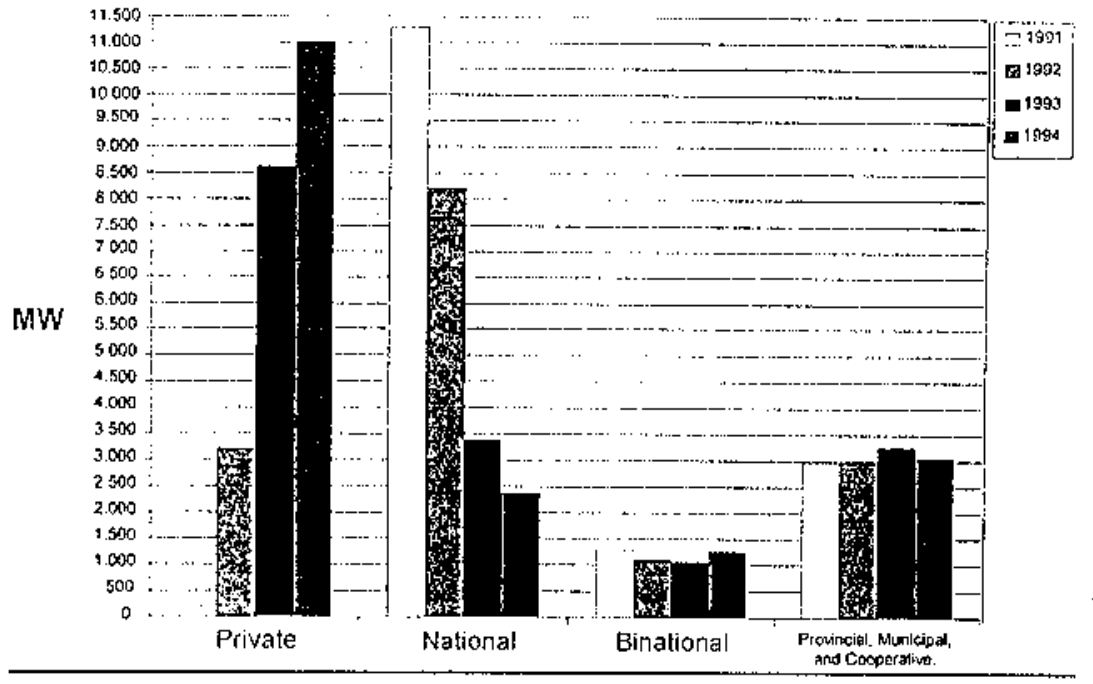

FIGURE 2 Instailed Capacity By Type of Ownership, Argentina. 
Finally, the higher are utility prices, the more attractive it is for large users to opt out of the system and instead generate their own power. When an uncertain matrec keeps prices high enough that self-generation is an atraictive alternative, self-generation should be faitly common. We note in this regatud that, in the absence of the political stabilization we identify with constitutional amendments and Ménem's reclection, self-generated dectricity in Argentinal was projected to rise from some $3400 \mathrm{GWh}$ in 194) to 5480 in the year 2000 (Covarrubios and Maia 1994b, A-42, Jigure 7). In the more certain political climate that prevails today, increased capital investment should improve economies of scale and hence prices, and future estimates of self-generation should decline. Indeed, it has, as the devclopment of new self-generation capacity has recently dropped to near zero, while co-generation has increased to take advantage of the mote favorable pricing structure ${ }^{28}$ Moreover, during the period from 1991 through 1994, the number of self-generators dropped from 1839 to $16014^{29}$

\subsection{Llectricity Regulation and Regulatory Outcones in Chile}

Throughout most of the 20th century in Argentina, frequent military coups and suspended constitutional processes led to increased political uncertainty and economic risks. Only recently has the winner-take-all quality of Argentine politics been seemingly overtaken by a spirit of compromisc. The military coup of Pinocher in 1973 overturned an admitable history of democratic politics. This led to a host of societal problenss, including both civil unrest and human rights viotations. Rather than inject an added measure of uncertainty to economic decision making, however, the legacy of Chile's nearly two decades of dictatorship is a high degree of stability in both the political regime and in regulatory policy.

P'rior to privatization, Argentina set up a profitable reversion for electric utility regulation and then set up a regulatory system that was predictable and, indecd, favorable to utilities. As discussed above, political and institutional changes served to reinforce this structure. Similarly, Pinocher set up a profitable teversion and predictable utility regulation process. This structure in Clite favored utility profit motives. ${ }^{30}$ Evidence of favorable conditions for investment is revealed in Table VIl, as we observe a change in prices that we can trace to carly in Pinochet's regime. Table VII shows an increase in the average annual tariff, for both residential and large industry consumers, when compating an carly five year period of Pinocher's rcgime with the last five year period of his tenure, after his new regulatory structure was given a
TABLE VII ANerage bectrical Encrgy l'ries in Chile (USS cent/kWh)

\begin{tabular}{|c|c|c|}
\hline & Rusidonthal Tirill & Latrige luetssing \\
\hline \multicolumn{3}{|c|}{5 Year l'eriod } \\
\hline $1975-79$ & 4.20 & 2.63 \\
\hline $1084-88$ & 8.91 & 4.15 \\
\hline
\end{tabular}

Nutces:

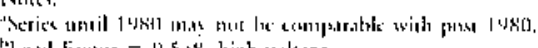

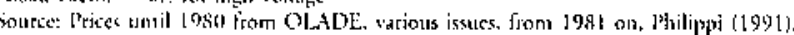

chance to settle in. ${ }^{31}$ Also note that, as expected, Chile's largest electric power supply company, ENDESA, has been quitc profitable over the same period (see Table VIII). ${ }^{32}$ Moreover, constitutional clange, making changes in the regulatory regime sustainable in the short run, allowed for more stable policies than we might otherwise predict. We now turn to examine the underpinnings of this stability in the context of Chilean electricity regulation.

As in Argentina, the elcerricity scctor in Chile is regulated by a single body - the National Energy Commission (CNE). Guidelines for elcetricity regulation are spelled out in fine detail in Mitistry of Mines Decree 1, 1982 (as amended by Law 18.922, 1990). Also as in Argentina, certain classes of scrvice are unregulated. In general, prices may be freely contracted for large users (over $2000 \mathrm{~kW}$ ), short-term service (less than twelve months), and users with special service requirements (DFL 1, Art.90).

While the law regulating electricity generation and distribution explicitly lcaves certain classes of service uniegulated, ir nonetheless links regulated and nonregulared prices. Decree 1, 1982, stipulates that the prices set by the

TABLL VII Chile: Avernge Electricity l'rices (US\$ cent/kW/h) and ENDESA Profits, 1982-1990

\begin{tabular}{|c|c|c|c|c|}
\hline Sive: & $\begin{array}{c}\text { Rosintonthl } \\
\text { Litriff }\end{array}$ & $\begin{array}{c}\text { Sinall } \\
\text { Industyr } \\
\text { Twifif }\end{array}$ & $\begin{array}{l}\text { Latrgr } \\
\text { Industy } \\
\text { Iariff }\end{array}$ & $\begin{array}{l}\text { ENDESA profits } \\
\text { (US \$milious) }\end{array}$ \\
\hline $198:$ & 8.80 & 7.55 & 5.52 & \\
\hline 1983 & 7.45 & 6.45 & 1.78 & 101 \\
\hline 1984 & 6.18 & 5.31 & 3.84 & 33 \\
\hline 1085 & 6.40 & 5.56 & 3.78 & -6.5 \\
\hline 1986 & 6.48 & 5.62 & 3.81 & 50 \\
\hline 1987 & 7.06 & 6.19 & 4.29 & 62 \\
\hline 1988 & 8.2 .3 & 7.60 & 4.78 & 179 \\
\hline 1989 & 9.24 & 8.62 & 5.65 & 106 \\
\hline 1990 & 8.77 & 8.18 & 5.17 & 104 \\
\hline
\end{tabular}

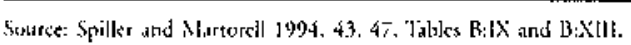


CNE "may not differ by more than 10 percent from contracted prices" in the nonregulated marke (law 24065. Art. 101). This clause ties the two classes of prices-regutated and unregulated-together and carries with it the potential to set up a rather interesting incentive structure for utility itvestment strategies.

In its rate-setring role, the CNE-again, like its Argentine counterpart-is supposed to talse into account the teal costs of producing, transmitring, and distributing electricity. To this end, it sets maximum allowable sates that are stupposed to reflect the long-run marginal costs of operations (Spiller and Martorell 1994, 36; Silva 1991, 25). The result is intended to approximate prices and profits under a comperitive market, not the rate-of-return regulation used prior to 1980 (Spiller and Martorell I994, 30).

\subsubsection{Tiriff Regulation}

Chitean ratc-scteing procedures makc rate setting predictable. Where ENRE in Argcutina must respond to all complaints and, often, hold public hearings, less is required of the CNE. In some cases, as when generating companics register complaints about what they see as unfair regulated rates, CNE is under no obligation to take any action at all (so long as regulated rates are within 10 percent of unregulated rates-DFL 1, 1982, Art. 101). in those cases where a response is required, the manner and degree of the response is spelled out in the law. This makes rate setting transparent and, along with the fact that costs are calculated on the basis of long-term investments (DFL 1, 1982, Art. 105), gives companies an incentive to invest in efficient and durable playsical plants.

lrices at the distribution end of the electricity pipeline are set on the basis of wholesale, or "node" prices plus value added in distribution. Node prices for electricity are set wice yearly to "reflect an average of the marginal costs of supply incurred in genetation and transmission" (DFL 1, 1982, Arr. 97). ${ }^{3,3}$ To the extent that capital costs are factored into this calculation, they are aggregated and averaged across all generating and tratisnitting compamies. Company-specific capital costs ate not included in the calculation of distribution value added. They are determined, along with administrative and operating costs, on the basis of a "model company" whose characteristics are defined by the CNE (DFL 1, 1982, Art. 106). In short, distributors (except, perhaps, CHILECTRA as discussed below) have little direct control orer prices. White they are assured of recouping their cost of buying electricity on the wholesale market, they have no such assurance with respect to returns on their capital investments. For that, they need to invest as efficiently as possible, in order to keep their own costs in line wirh those of the CNE's "model" company.

In defining the tariff-influencing characteristics of a "model" company, and hence the costs that utilities may recoup through tariffs, the CNE divides companies into thee classes: "Low density" (of which there are seven) companies, with fewer than rwenty thousand custoners; "nzedium density" (seventeen) comparies, with between twenty thousand and one million customers; and "high density" (one-CHILECTRA, a publicly owned integrated company) companies that serve over one million users (Spiller and Martorcll, 32). "Model" costs are set separately for each class of company, and how closely they approximate costs for companies in a competitive marker depends on how accurate are the CNE's calculations, which depend crucially on how competitive the market actually is. As the best source of informution on company costs is the companies themselves, estimated costs for medium-density companics should be fairly accurate, costs for low-density companies should be somewhat less accurate, and costs for the single high-densiry company ought to be overestimated.

As noted above, regulated wholesale prices are set to reflect generating companies" long-run marginal costs. The twist to this scheme is that CNEdetermined node prices. "cannot diverge by more than 10 percent from prices [for equivalent tension and power levels] not subject to price regulation" (DFL 1, 1982, Art. 101). The intent here is to ensure that nodal prices do not diverge too much from market prices. If generators can use regulated prices as a focal point for collusion, however, this creates an interesting incentive problem with regard to whether to sell their output in the unregulated or the regulated market: The problem is, the existence of the regulated market could take the competitive pressure out of the unregulated market. As in any free market, the fewer companies that compete in the unregulated markct, all else constant, the higher will be the unregulated price and, therefore, the regulated price as well. A company that does not enter into the unregulated market is not, however, denied the ability to sell its product. On the contrary, it can then sell its output on the regulated market at gitumtecd prices. Hence, collusive, cartel-like behavior would be rewarded through higher prices on the regulated market.

There is in fact no fixed reversionary tariff in Chile, although the reversionary tariff is predictable and depends on market forces or, absent a competitive market, on well-defined formulas for approximating a market. The reversion is essentially whatever the market witl beat, and firms that allocate investment incfficiently will see their profits drop as a result. To the extent 
that the regutatory formulas are well-designed, then, electricity pricing strould contributc to more ethicient economic development in general.

\subsubsection{Results of Chilenth Electricity Regulation Reform}

On lle one hand, then, investment capisal should have gravitated coward Chile's electric tutlities. Further, as such investment would have been channeled into efficion generation and transmission facilities, Chile shotald have seen an impressive increase in installed capacity over the same period. On the other hand, to the degree that generators operate in tncomperitive markets (due to market structure or to collusion), and to the degrce that CHILECTRA acts as a monopolist is in the single largest market in Chile, clectricity prices should have held steady or at least dropped far less than might be expected given the increase in installed capacity. As a result, electricity generation should be highly profitable in spite of the CNE's continuing efforts to set tariff rates equal to long-term marginal costs and, thercfore, bring profits down to minimal levels.

What we observe in Chile mects our expectations. As can be seen in Table IX, the amount of electricity generated in Chile has risen steadily, with prices changing little throughout the 1980s, as seen in Table VIII. Further, clectricity self-gencration has continued to rise since privatization (sec Spiller and Martorell 1994, 41, Tables B:VI and B:VII). This suggests that prices still are high enough to make it worthwhile for relatively inefficient producers to continuc generating electricity rather than buying it off the grid.

Chik's clectricity regulatory system has sparked new investment. The question is, what are the chances that this particulat regulated system will last?

'Throughout P'inochet's rcgime (1973-89), Chile's govemment focused on economic liberalization and political stability. By the time Pinochet left power, the electricity sector was just one of many segments of the economy that had been privatized and opened up to market forces. In essence, the free market became the reversionary policy, which we will argue next is well-protected by the Constitution that Pinochet introduced in 1980.

\subsubsection{Regime Stability}

Chile's Constitution privileges the status-quo policy. Chile bas a separation of powers system with a bicameral legislature, like Argentina, with each chamber possessing a veto over policy. Rules that skew representation in favor of conservarive, rural areas, and a two-member district system that
TABLE IX Elecricity Generation. Chile (thousands of $\mathrm{kWh}$

\begin{tabular}{lc}
\hline Sour & Total \\
\hline 1989 & $17,727,469$ \\
1990 & 18.321 .400 \\
1991 & $19,807,554$ \\
$19)^{\prime 2}$ & $22,167,280$ \\
$1993^{2}$ & $23,331,924$ \\
\hline
\end{tabular}

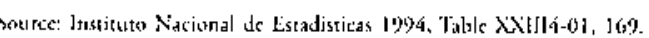

"freliminary.

gives a strong boost to the second-strongest party in a district virtually guarantee that the policies put in place under Pinochet always have the ability to veto changes to those policies. Not only is it difficult for a single party to win more than 50 percent of lower-house scats (see Caviedes 1991; Godoy Arcaya 1994), a constitutional provision (Const. Art. 45) for appointed (eight-year terms) and lifetime senators has thus far denied a senate majority to Pinochet's old antagonists. ${ }^{35}$

As a resulr, it would be very difficult for a government that sought to reverse policies enacted under Pinochet's rule to do so. Unless Concertación lists and candidates begin to win by overwhelming majorities in the bulk of the country, their opposition will likely always hold a powerful check. And even if the Concertación were to sweep aside its opponents, it remains in effect a coalition of parties with distinct policy goals (sce especially, Drake 1993, 4; Auth 1994, 347). As it stands now, the present governing coalition-onetime opponents of Pinochet and, it was presumed, all he stood for-stands in support of econonic liberalism and the economic model promoted by Pinochet's regime (Godoy Arcaya, 305).

Drastic changes in regulatory policy or goals, therefore, are unlikely in Chile. Those who might oppose current policies cannot expect to control all the various segments of the policy making process, so they cannot expect to change policy. Moreover, if 1993 electoral outcomes are any indication, voters approve of the liberalizing bent of the current government. Perhaps more to the point, Pinochet and the military returned to the barracks, but they still pose a tacit threat to all who might consider significantly changing the status quo. This situation will remain unchanged until 1997, when the balance of power in the Senate may shift as a result of the appointment of eight new members by the president. 


\section{Conclusion}

Clile's success in privatizing the electricity sector fand other tuilities, stuch as telecommunications) has been seen as a victory for institutional engineering. Chile's privatized electricity sector seems to have developed steadily and liealthily over time, while Argentina's development looks much more er. ratic. Now that Argentina has privitized electric utilities, the question arises as to whether its development will begin to parallel that of Chile. Spiller and Martorell (1994) argue that it will not, because Chile has had the time to develop calmly, with "strong political support for maintaining the financial viability of the companies," an opportunity denied Argentina. Further, clectricity regutation in Chile is decentralized, while in Argentina it remains cenrralized in the federal governnent (Spiller and Martorell 1994, 49).

'There is undoubtedly much truth to this view. The level of regulatory risk, after all, is tightly linked to the ease with which regulatory procedures allow regulators to force utilities to reallocate the incidence of charges, for cximple. We have argued here, however, that investment strategies look to in much more basic source of risk: regime instability. While this has been only a distant concern in Chile, it has been an urgent concern in Argenrina. But, the furure may bring changes. We contend that constiturionil retorm has transformed Argentine politics to some extent, providing a foundation for profitable enterprise comparable to that built up over many years in Chile. By contrast, changes in the makeup of the Chilean Senate could constiture a shift in its policy preferences, as we expect the new appointees to be either part of the president's party or at least members of a party other than the Conscrvatives. In Argentina, now that the constitutional incentives lead to compromise and not confrontation (and the milisary threat is but a pale caricature of what it once was; see, e.g., Calvin Sims, "Argentine Military for Rent; Turns Swords into Tin Cups," The Now York Times, Jantury 29, 1996, A1), investors and firms can look forward to a more favorable future.

The rask for any govertment that wishes to privatize its utilities is to establish a regulatory structure that is both favorable to private investment and sustainable without sacrificing service. Private entities must be satisfied that the political risk of investing in tegulated utilities is counterbalanced by a sufficiently tempeing expected rate of return. If, however, the rate of return is not exorbitantly high, then cautious investors nust be convinced that a more conservative rate of return is politically sustainable. Our theory of privatization and political risk establishes that regulatory predictability and regime stability are two conditions that encourage private investment in public urilities. When a government and its regulatory structure meet these conditions, private investors can reasonably conclude that the commitment to the process is credible. Evidence from Argentina and Chile, as presented here, indicates that these conditions are, in fact, critical to the economic growth of key sectors within developing mations.

\section{Acknowledgement}

This paper was made possible through support provided by The World Bank and by the US Agency for International Development under Cooperative Agreement No. DHR-0015-A-00-0031-00 to the Center on Institutional Reform and the Informal Sector (IRIS) and administered by the Office of Economic and Institutional Reform, Center for Economic Growth, Burcau for Global Programs, Field Support and Research. We owe thanks to Scott Basinger, Greg Bovitz, Randy Calvert, Andrea Campbell, Jolan Carey, Paul Drake, Félix Helou, Mark Jones, Dan Kaufman, Hanna Robles, Roberr Schwartz, Pablo Spiller, Mike Thies, and two anonymous reviewers.

\section{References}

Auth, Josć. (1994) "Elecciones presidenciales y parlamentarias de 1993," Estudios Públicos (fall): $339-361$

Campos. Jose Edgardo and Hadi Salehi Esfahani. (1994) "The Political Foundations of Public Enterprise Reform in Developing Countrics." Typescript, The World Bank, Washington. DC. Cavicdes. Cesar. (1991) Elections in Chile The Road toward Redemocratization. Boulder,
Colo.: Lynnc Rienner.

Covarrubios, Alvaro J. and Suzannc B. Maia. (1994a) "Reforms and Privare Participation in the Power Sector of Selecred Latin American and Caribbean and Industrialized Countries," v. 1, Discussion of lssues. Diaft report \#33, World Bank, Latin America and the Caribbean Technical Department, Regional Studies Irogram, March. Covarrubios, Atvaro J. and Suzanne B. Maia. (1994b) "Reforms and Private Participation in
the Power Sectot of Selected Latin Amcrican and Caribbean and Industrialized Countries," v. 2, Appendices. Drafr report \#33. World Bank, Latit Ametica and the Caribbean Technical Department, Regional Srudies Program, March.

Cox. Gary W. and Matthew D. McCubbins. (1996) "Structure and Policy: The Institutional Detcrminants of Policy Outcomes." Typescript. UC San Dicgo. Paper prepared for a conference on Adninistrative Procedure. San Dicgo, June 1996.

Cox, Gary W. and Richard D. McKclvey. (1984) "A Ham Sandwich Theorem for General Mcasures," Social Choice and Welfare I, 75-83.

Drake, Paul. (1993) "Obsrackes to Policy Changes in Chile," "Fypescripe, University of Cillifornia, San Dirgo.

Enelow, James and Melvin Hirich. (1984) The Spatial Theory of Voting. New York: Cambridge University Press.

ENRE. Ente Nacional Regulador de la Electricidad. (1994a) Informe Anmal 1993/1994, vol. 1. Bueros Aires: ENRE.

ENRE. Ente Nacional Regulador de la Electricidad. (1994b) Informe Anual 1993/1994, vol. ?. Buenos Aires: ENRE. 


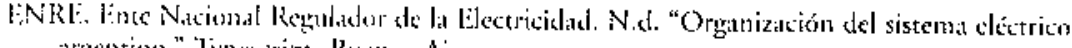
argentino." 'Typescript, Buenos Aires.

Godoy Araya. Oscar, (1994) "Las clecciones de 1993." Estudios Priblicos (fill):301-337.

Gormaikz liaga, lavier. A. (1991) "Argentine Privatization in Retrospect." In Pritutization of

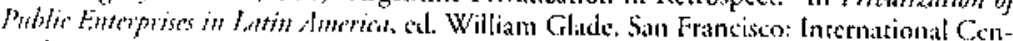
(e) for Fionomic Growth, Instirute of the Americas, and Center for US-Mexican Studies.

Hammen. Paul. (1993) Argemim: A Nete La. Londom: Euromoncy Publications.

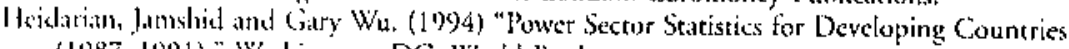
(1987-1991)." Washingem, DC: World Bank.

Hill, Alice and Manned. Angel Abdata. (1996) "Argentinat The Sequencing of Privatization and Kcgulation" in levy: Brian and Pablo T: Spiller (eds.) Regulations, Mnstitutions, and Commitment Comparative Studics of Telecommanications. Cambridge: Cambridge University Press.

Hog,an, William. (1996) "Evaluation of Aternatives for Power System Coordination and Peoling in a Compretitive Enviromment." Paper prepared for prescntation ac the IFEE Plis Winter Aeecing, Balcimore, Maryland, January 21-25.

Hutcling. Hatold. (1929) "Stability in Competition," Economic foumal, 39, 41-57.

foncs. Natk P. Porthcoming. "Evaluating Argenrina's Bresidential Democracy: 1983-1995," In Prsidentatism and Demotraty in Larin America. Cambridge and New York: Cambridge University Press.

Jowkow, biul L. (1974) "Inllation and Linvitonmental Concern: Structural Clange in the Process of I'ublic Utility Price Regulation," Journal of Latw and Economics, 17, 291-327.

Joskow, Jaul L. and Roger G. Noll. (1981) "Regulation in Theory and Practice: An Overview." P'p. 1-65 in Studies in Pablic Regilation, ed. Gary Fromm. Cambridge: MIT Press.

Juskow. Patul L. and Richard Schmalensee. (1983) Markets for power an analysis of electric unitity dercgutation. Cimbridge: MIT Press.

Kalun. Lidward and Richard Gilbert. (1994) "International Comparisons of Electricity Regulation." Paper presented at the 17 th anmual International Conferences of the fntern tional Assoctation of Energy Licononists, Stavanger, Norway, May.

lew Brian and P'iblo T. Spiller. (1994) "The Institutional Foundations of Regulatory Commitment: A Comparative Analysis of Telecomnunications Regulation." Joumd of Lam Economics. and Organiastion 10, 201-245.

Lew Brian and ['ablo T. Spiler, eds. (1996) Regulations, Lnstitutions, and Commitment Componatite Stwdies of Telcommunications. New York: Cambridge University Press.

bijphare. Arend. (1984) Democracics. New Haven, Conn.: Yale Universiry Press.

Limz, Juan J. (1990) "lhe Perils of Presidentialism," Jowrnal of Democracy, 1, 51-69.

MeCuthins. Marhew D. Roger Noll and Barry Weingast. (1989) "Strucrute and Process, l'olitics and Policy: Administrative Arrangements and the Political Conrol of Agencies." Virginis Late Retiowe, 75, 431-482.

Milgrom. Paul R., Douglass C. North and Barry R. Weingast. (1990) "The Role of Institutims in the Rovival of Trade: The Law Mercluatr, Private Judges, and the Champagne lairs." Fionomics and Politics, 2, 1-23.

Milyrom. Paut R, and John Roberts. (1992) Economics, Organization, and Managenent. New Iersey: Prentice Hall.

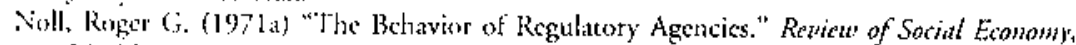
29, $15-19$.

Noull, Roger (i. (1971b) Reforming Regulation. Washington DC: Brookings Institurion.

Noll, Roget G. (1985) "Covernment Regulatory Behavior: A Multidisciplinary Survey and Synthesis" in Roger (j. Noll, ed. Regulatory Policy and the Social Sciences. Berkelcy: University of Califotuta l'ress.

Notl, Roger 6. (1989) "Eonomic I'erspectives on the Politics of Regulation" in Richard Sithmalensec and Rober Willig, ods. Handbook of Indistrial Organization, Volime II. Amsterdaten: North-Holland.
Noll. Ruger G. and Bruce Owen. (198.3) The Folitiont Ecomomy of Dorgthlation. Waslingron DC: Anericals Enterprise Insticute.

North. Douglas C. (1990) Intitutions, instituriond change, and economic performance. New York: Cambridge Universiry Press.

North, Douglass C. and Barry R. Weingast. (1989) "Constitutions and Commitment: The Evolution of Institutions Govetning ['ublic Choice in Seventecentl-Century England."

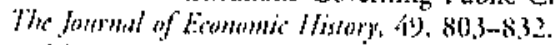

(3son. Mancur. (1965) The logir of collectine action phtilic goods and the theory of groups. C.mblidge: Howvird University l'ress.

Rausch. Aljandro E. (199.3) "Privatization in Argentina." In Constnithes and Impacts of Priatization, ed. V. V. Ramanadhan. London and New York: Routledge.

Roon. Hilton L. (1994) The Fomtain of Privilege. Political Fondations of Economic Markets in Old Regime France and England. Berkcley: University of California Press.

Silva, Ernesto. (1991) "El nuewo niño prodigio de la bolsa." Administración y Economia U.C. Rerista de la Fantad de Ciencias Economicas y administrativas de la Universidad Católica, 5. $2.3-28$.

Spiller, Pablo T. and Luis Viana Martorell. (1994) "How Slould It Be Done? Electrictity Regulation in Argentind, Brazil, Uruguay and Clile." Typescript, University of California, Berkeley.

Tsebelis, George. (1993) "Decision Making in Political Systems: Comparison of Ptesidentialism. Parliamentarisn, Multicaneralism, and Multipartism." Duke Universiry Program in Political Economy, Working Paper No. 178, May.

Williamson, Oliver. (1985) Econonic Institutions of Capitalism. New York: Free Press.

Williamson, Oliver. (1983) "Credible Commitments: Using Hostages to Support Exclaange." American Economic Retietw. 73, 519-540.

World Bank. (1995) Bureatchts in Business: The Economicr and Politics of Government Ownership. Washington D.C.: The World Bank.

Decreto con Fuerza de Ley $\mathrm{N}^{\circ} 1$, Minería, 1982 (Chile)

Ley N"18.922 ("Modifica el decteto con fuerza de ley 1, de 1982, de Mineria"), Diario Offial $\mathrm{N}^{\circ} 33.594$, February 12, 1990 (Chile).

Decreto N" 1398/92 ("Energia cléctrica") (Argentina).

ENRE, Ence Nacional Regulador de la Electricidad. Resolución ENRE No. 39/94, Anexo, "Reglamento de Audencias Públicas." ln ENRE 1994b (Argentina).

Ley N"24.065 ("Energia cléctrica") (Argentina)

Ministcrio de Ecomomía y Obras y Servicios Públicos, Scctetarla de Energía Electrica. 1992 Resolución S.L.E. No. 170, "Contrato de Concessión Edenor S.A." Buenos Aires: Ministerio de Economía y Obras y Scrvicios P'úblicos (Argentina).

\section{Endnotes}

1. Political meddling and economic inefficicncies are not confined to low-and middleincome economies. In developed economies, government regulation of utilitics is used essencially as inefficient tax policy.

2. The first of these problems is essentially incscapable and not necessirrily objectionable Gowernment intervention to stapply demanals not met by the market can be justified on grounds other than economic (e.g, moral), just as it is wcll-recognized that matket forces will tend to undersupply imporant collective goods (Olson 1965). Levy and Spiller $(1994,204)$ pur it succinctly: "Widespread domestic consumption implies trat che pricing of utilities is always going to be political."

3. On the politics of utility regulation, see Noll (1971 a, 1971b, 1985, 1989), Joskow (1974). Joskow and Noll (1981), Joskow and Sclimalensec (1983), and Noll and Owen (1983). 
4. This could include cxchange rate risk, capital asset accounting risk, and all forms of regulatory risk.

5. We detine "extreme" here as a point sufficiently far from all the veto players" ideal point.

6. For a discussion of the Sharper-Lintunct capital asset pricing model, see Milgrom and Rolwers (1902: $464-467)$.

7 . Lewy and Spiller (1994, 205 and ff.) use the tetms "regulatory governance" and "regulatery incentives" to teler to the same essential issues.

8. Conversely: where citluer the "execurive has strong legislative powers" or the legisharture hiss tight control over the exceutive, credibiliry should be more scarce (Levy and Spiller $1994,207)$

4. Stable polictics or processes, lowever, do not necessarily encourage investment. Current policy mily be difficult to chatnge hut averse to investment. Therefore, the investors must waluate the degree to which the feversionary policy suits their goals for rate of return.

10. Sece for cxample, Enelow and Hinich 1984.

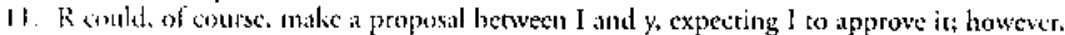
if $R$ is a welfare-maximizing actor, then it would be irrational to propose anything to the keli of $y$

12. Alectnicively, the utility can be made worse off in the reversionary ourcome moves from Q' to Q because $\left|I-y^{\prime}\right|<|I-y|$ and the equilibrium outcome under the new reversion. Q. is $x$

1.3. 1 is the cyuilibriam outcome in ligure $1(b)$ whan the utility is the agenda scttct. regardiess of whether the regulator has a veto.

14. The contrast stems from the mirtoring principle (MeCubbins, Noll, and Wcingast 1989, 444). Argentina's tegulatory rcgime, open to participation (and to conflict) on all sikses, reflects Argentine politics as that country works to shake off its turbulent political past. And Chile's regulatory regine, insulared from politics and latgely free from the noed to respond to contlict, reflects Pinochet's position and power at the time el legisneed to respond to cont
hator set it into law.

15. 'The process began in 1989 , but the first sales took place in 1992

16. Onc transmission firm, Ttanscomalne, was bought by the provincial-government firms EE'PN and LESE.

17. Note that the rules governing implementation of the electricicy law prohibit owners of generating facilitics from holkting licenses to distribute etectricity (decree $1398 / 92$. Art.9)

18. The spot price is calculated hourly by the Compañla Administradora del Mercado Mayorista Ekcorico Sociedad Anónima (CAMMESA)

19. In periods of high demand, therelore, the "spot" price will be much greater than the production cost of the most efficient producers.

20. A producer's market is a "spor" market where the price is calculated by a company dcelicated only to that task (c.g., in Argentina, CAMMESA).

21. This price combines long-term estimates of the output of che most cconomical production techmology (over the long term) available (i.e., hydroelectric), weekly estimates of the prebability of breakdowns and the concomitant costs of ensuring sufficienr capacity (1) Itaintain utrinterrupted supply, and daily calculation-given tnput availability (for example, bydroetectric Beneration grows more expensive during dry spells)-of the most
cfficient type of generatot. Decisions as to the standard for an efficient generator, as well as estimates of future demand and probability of breakdowns, are made by the regulatory body. leaving guite a bit of keway for the "spot" price to differ from what would be the free-market price.

22. Un[ess olkerwise specified, we shall refer generically to distribution companies to cover hoth aspects of supply. W/e focus mainly on distribution, not because regulation of itansmission companies is transparent or uninteresting-is is not-bur because transtmission-specific regulations are in a different catcgory from distribution. In any case, the fixed transmission prices atc factored into retail prices straightforwatdly:

23. This only gives the licensec partial control over the reversion besause, should ENRE lases reject the requested cliange, the licensec must scturn to the old rare structure and reimburse customers tor any difference in payments (Law 24065, Art. 47). How this plays out. however, is as yet unclear. ?herefore, industry's role in agenda serring remains a potent tool for investors to help ansure the preservation of proficable regulatory structutes.

24. As of 1991, average revenuc for eiecricity (total sales divided by tocal sales in Gwh) was only 79 percent of avetage financial cost, defined as total operating cost, plus payments on debt interest and principal, minus depreciation, divided by total sales in Gwh (Campos and Esfalaani 1994, "Fable IIb).

25. The losses in the first couple of ycars after privatization can be atributed to the enormous inefficiency of the state-run companies, which the private owners inherited.

26. The tible shows the tariff structure for EDENOR S.A., one of the three regionitmonepoly distribution companics that were created from SEGBA's distribution network. The orher nwo, which have similar tariff structures, are EDESUR S.A., and EDELAPS S.A. More recen ENRE Jata, supplicd by Hanna Robles, confirm that this trend has continued into early 1996.

27. The situation for transport companics is murkicr, as chey remain heavily regulated and are permited to invest only on request from electricity generators or buyers (we thank Hanna Robles of ENRE for this clarifying observation).

28. As noted in a petsonal communication with Felix IFelou, legal advisor on cconomic regulation at ENRE. Also, sce hetp:/www.mecon.ar/encrgia/cnetg anuario/zip/ capa.htm which contains "INFORME DEL SECTOR ELECTRICO" of the SUBSECRETARIA DE ENERGIA, Dirección Nacional de Prospectiva, MINISTERIO DE ECONOMIA Y OBRAS Y SERVICIOS PUBLICOS SECRETALUA DE ENERGIA, TRANSPORTE Y COMUNICACIONES, Republic of Argentina.

29. See hetp://www.meconiar/energia/energ_anuario/tip/tapa.him

30. It is interesting to note that l'inochet, whilc raising tariffs to encourage privare investment, continued to favor the agriculture sector with moderate, consistent prices. This is unsurprising, since the agriculture sector is a key supporter of his regime.

31. In 1981, electricity prices were higher than the average price for the rest of the $1980 \mathrm{~s}$ We attribure this to the conomic volatility and political uncertaincy that marked the time at the begining of Pinocher's rise to power.

32. The dip ino umprofitability in 1985 coincides with bad economic times in general.

33. Node prices "are computed using indexing formulac that depend on fuel costs, equip. ment costs, dam levels, exchange rate, and so on" (Spiller and Martorell 1994, 37).

34. The CNE-defined "model" company represents a "typical," efficient firm. Existing distribution and transmission companies can clallcnge the CNE's estimates, howeve (DFL 1, 1982, Art. 107). When challenged, the CNE may accede to the utilitics" estimates of costs; if not, then the characteristics of a "model" company are caiculated as a weighted average of $\mathrm{CNE}$ and industry figures. This rule gives electric urilities as a group a fair amount of indirect authority to set their own tates.

35. Pinocher's government appointed its own supporters to the Senate positions. In the 1989 dections that preceded I'inoche's withdrawal from die foreftont of politics, fluc opposition Concertación won about 58 percent of the elected seats in both the House of Deputies and the Senate. It was able to occupy only 47 percent of Sente seats, however, because of the designated senators. In 1993. Concertación parcies jointiy won about 55 percent of elecied Senate seats, but only 46 percent of total Scnate scars. The Concertación's shate of the popular vote in 1989 and 1993 was 52.1 and 55.5 percent, tespectively' (Auth 1994, 347). 